\title{
Physiological behavior of melon cultivars submitted to soil salinity ${ }^{1}$
}

\author{
Valéria Fernandes de Oliveira Sousa ${ }^{2}$, Caciana Cavalcanti Costa², \\ Genilson Lima Diniz², João Batista dos Santos², Marinês Pereira Bomfim²
}

\section{ABSTRACT}

Melon is one of the most important vegetables for the Brazilian foreign trade. However, in semi-arid areas, the irregular rainfall, excessive use of fertilizers and, especially, poor quality water contribute to the soil salinization, becoming a limiting factor and damaging the photosynthetic apparatus, as well as affecting yield. This study aimed to evaluate the physiological behavior of melon cultivars submitted to soil salinity. For that, an experiment was conducted in a greenhouse, using a randomized block experimental design, in a 3 x 5 factorial scheme, with the first factor related to melon cultivars (Iracema, Goldex and Natal) and the second one related to soil salinity levels $\left(0.3 \mathrm{dS} \mathrm{m}^{-1}\right.$, $1.3 \mathrm{dS} \mathrm{m}^{-1}, 2.3 \mathrm{dS} \mathrm{m}^{-1}, 3.3 \mathrm{dS} \mathrm{m}^{-1}$ and $4.3 \mathrm{dS} \mathrm{m}^{-1}$ of electrical conductivity), with four replications. For soil salinization, a saturation extract with initial soil salinity of $0.3 \mathrm{dS} \mathrm{m}^{-1}$ was obtained, while the other levels were prepared by adding $\mathrm{NaCl}$ to the soil. The physiology of melon plants is negatively affected by the increased salinity in the soil. The evaluated cultivars do not show differences in tolerance for the physiological response to soil saline stress.

KEYWORDS: Cucumis melo L.; salinated soil; gas exchange.

\section{INTRODUCTION}

Melon has a great economic value in the Brazilian market, being one of the crops with the highest growth rate for vegetables exported by the country. In 2016, Brazil ranked 12th in the world production scale, being the largest melon producer in South America, with a national average yield of $25,814 \mathrm{~kg} \mathrm{ha}^{-1}$ (FAO 2017, IBGE 2017). Besides the economic and food influence, Brazil also has a great social relevance in the generation of direct and indirect jobs in the Northeast of the country, the

\section{RESUMO}

\section{Comportamento fisiológico de}

cultivares de meloeiro submetidas à salinidade do solo

O meloeiro é uma das hortaliças-fruto de maior relevância para o comércio exterior do Brasil, mas, em áreas semiáridas, a irregularidade de chuvas, o uso excessivo de fertilizantes e, principalmente, a escassez de água de boa qualidade contribuem para a salinização dos solos, tornando-se um fator limitante, com danificações ao aparato fotossintético e à produtividade. Objetivouse avaliar o comportamento fisiológico de cultivares de meloeiro submetidas à salinidade do solo. Conduziu-se um experimento em casa-de-vegetação, utilizando-se delineamento experimental de blocos casualizados, em esquema fatorial $3 \times 5$, sendo o primeiro fator cultivares de meloeiro (Iracema, Goldex e Natal) e o segundo níveis salinos do solo $\left(0,3 \mathrm{dS} \mathrm{m}^{-1} ; 1,3 \mathrm{dS} \mathrm{m}^{-1} ; 2,3 \mathrm{dS} \mathrm{m}^{-1} ; 3,3 \mathrm{dS} \mathrm{m}^{-1}\right.$; e $4,3 \mathrm{dS} \mathrm{m}^{-1}$ de condutividade elétrica), com quatro repetições. Para a salinização do solo, foi obtido extrato de saturação com salinidade inicial de $0,3 \mathrm{dS} \mathrm{m}^{-1}$, preparando-se os demais níveis mediante a adição de $\mathrm{NaCl}$ ao solo. A fisiologia das plantas de meloeiro é afetada negativamente, com o aumento da salinidade no solo. As cultivares avaliadas não apresentam diferenças para tolerância, em resposta fisiológica ao estresse salino no solo.

PALAVRAS-CHAVE: Cucumis melo L.; solo salinizado; trocas gasosas.

largest producing region, since a large amount of labor at all stages of the production system is required (Dalastra et al. 2016).

In the Brazilian Northeast region, the Polígono das Secas (polygon of droughts) is still considered a region little explored. Paraíba, from an agricultural point of view, stands out as a state affected by an irregular rainfall regime. These characteristics are limiting factors for agricultural development, significantly compromising the yield of agricultural crops (Santos Júnior et al. 2011). Most of the time, the water available for irrigation has a moderate salt 
concentration (Lima et al. 2017a), resulting in an excess of ions in the soil, which are reduced during water shortage periods.

In saline conditions, plants may suffer water deficit from the lowest water potential in the root, as well as ionic toxicity associated with excessive absorption, mainly of toxic ions $\left(\mathrm{Cl}^{-}\right.$and $\left.\mathrm{Na}^{+}\right)$, leading to nutritional imbalance due to a reduction in the absorption and/or transport to the shoot, thus reducing growth and yield (Taiz et al. 2017). However, the plants behavior is differently affected by salinity, due to their development stage (Dias et al. 2011) or genetic divergence. Salt tolerance, even being relatively low in most cultivated species, may occur with a great genetic variability, not only among species, but also among cultivars within a species, as in melon crops (Terceiro Neto et al. 2013). Araújo et al. (2016) observed a salt tolerance variation in three melon cultivars (Gaúcho Redondo, Gaúcho Casca de Carvalho and Halles Best Jumbo), with Halles Best Jumbo proving to be more tolerant and Gaúcho Redondo more sensitive to water salinity.

It is known that photosynthetic efficiency is the first physiological target of environmental stress, such as high temperatures, lack of water in the soil and salinity (Liu \& Huang 2008, Munns \& Tester 2008, Chaves et al. 2009). Regarding salinity, under stress conditions, the inhibition of the electron transport used in photosynthesis and the enzyme activity of the Calvin cycle is observed (Esteves \& Suzuki 2008). Therefore, the reduction of photosynthesis leads to a decrease in yield, since the production index may reduce up to $50 \%$ under salinity conditions (Cruz et al. 2017).

Consequently, studies that make possible the selection of cultivars adapted to salinity are important (Medeiros et al. 2014, Araújo et al. 2016, Pereira et al. 2017), but those that approach the influence of salinity on the physiological mechanisms involved with the photosynthetic efficiency related to the variability of melon cultivars are rare, as the study of Akrami \& Arzani (2018), who analyzed the salinity interference on the physiology of 17 melon cultivars, observing a genotypic variation for all the physiological characteristics and concluding that the Sabouni and Shahabadi-1 cultivars are more tolerant.

With the constant inclusion of new hybrids with differentiated genetic variations in the market, their evaluation under different edaphoclimatic conditions is also necessary, especially those found in producing regions. Therewith, the present study aimed to evaluate the physiological behavior of melon cultivars under soil salinity levels.

\section{MATERIAL AND METHODS}

The experiment was conducted in a greenhouse covered with a shading net (50\%), at the Universidade Federal de Campina Grande, in Pombal, Paraíba state, Brazil (6 $6^{\circ} 48^{\prime} 16^{\prime \prime} \mathrm{S}, 37^{\circ} 49^{\prime} 15^{\prime \prime} \mathrm{W}$ and average altitude of $144 \mathrm{~m}$ ), from February to May 2017. The average temperatures during the experiment varied from $22{ }^{\circ} \mathrm{C}$ to $33^{\circ} \mathrm{C}$, with an average relative air humidity of $60 \%$.

The randomized block experimental design was used, in a $3 \times 5$ factorial scheme, with three hybrid melon cultivars from the yellow group (Natal, Iracema and Goldex), submitted to five soil saline levels $\left(0.3 \mathrm{dS} \mathrm{m}^{-1}, 1.3 \mathrm{dS} \mathrm{m}^{-1}, 2.3 \mathrm{dS} \mathrm{m}^{-1}, 3.3 \mathrm{dS} \mathrm{m}^{-1}\right.$ and $4.3 \mathrm{dS} \mathrm{m}^{-1}$ of electrical conductivity), with four replications, totaling 60 experimental plots or units.

The Iracema hybrid is resistant to the powdery mildew breeds $1,2,3$ and 5, fusarium breeds 0 , 1 and 2 and papaya ringspot virus watermelonstrain (PRSV-w). It has a good uniformity of size and a high stability of soluble solids. Goldex is tolerant to the fusarium breeds 0 and 2 and powdery mildew, with a high soluble solids content. Its pulp is white and its bark a little rough, with a weight average of $1.4 \mathrm{~kg}$. Natal is resistant to the breeds 2 of powdery mildew and 0 and 1 of fusarium. Its fruits have an oval shape and an average weight of $1.2-2.0 \mathrm{~kg}$. It has a firm white pulp, with a smooth bark. Its cycles are around 65 days and the productive potential exceeds $20 \mathrm{t} \mathrm{ha}^{-1}$ (Mendes et al. 2010, Castilhos 2012).

For the application of the experiment, plastic pots with capacity of $20 \mathrm{~L}$ were used. The distribution of the pots occurred with a spacing of $0.9 \mathrm{~m}$ between rows and $0.7 \mathrm{~m}$ between plants. A hole in the lower lateral part of the pots was made and a collector was placed for drainage. In the lower part of each pot, from the inside, a mosquito net was placed, overlapping the hole made, to prevent soil loss.

The soil (ground and sieved) used to fill the pots was collected at a depth of $0-20 \mathrm{~cm}$. The pots were filled with a mixture of $20 \mathrm{~kg}$ of soil and $2 \mathrm{~kg}$ of bovine manure. Soil and manure analysis were performed prior to the installation of the experiment (Table 1).

The salinity levels of the soil saturation extract were obtained by dissolving sodium chloride $(\mathrm{NaCl})$, 
calculated according to the treatments, considering the initial soil salinity $\left(0.3 \mathrm{dS} \mathrm{m}^{-1}\right)$, soil weight per pot $(20 \mathrm{~kg})$ and the saturation percentage $(23.3 \%)$ (Richards 1954). Before the transplanting process, the necessary volume of water was determined for the soil to reach the field capacity through the capillary saturation method, followed by drainage by applying saline water according to the treatments, being incubated for 15 days, maintaining the soil in field capacity with saline irrigation until reaching the electrical conductivity of each treatment in the soil saturation extract.

Fertilization was performed according to Novais et al. (1991), with simple superphosphate $\left(\mathrm{P}_{2} \mathrm{O}_{5}\right)$, at the dose of $300 \mathrm{mg} \mathrm{kg}^{-1}$ of soil, and applied on foundation, one day before transplanting. Potassium fertilization was divided into four applications, with potassium chloride $(\mathrm{KCl})$ being applied at a dose of $150 \mathrm{mg} \mathrm{kg}^{-1}$ of soil. Five days after transplanting (DAT), 1/4 of the $\mathrm{KCl}$ dose was applied and the remainder was applied in equal portions every 13 days. The nitrogen source used was urea, applied at a dose of $100 \mathrm{mg} \mathrm{kg}^{-1}$ of soil, divided into six applications, the first one at 5 DAT and the other ones every 8 days.

Sowing was carried out in polyethylene trays with a capacity of 128 cells, filled with commercial Basaplant ${ }^{\mathbb{R}}$ substrate. The seedlings were transplanted to the pots as soon as they presented four definitive leaves.

The water used in the experiment, provided by the Companhia de Água e Esgotos da Paraíba supply system, has its characteristics described in Table 2. The irrigations were carried out daily by manually maintaining the soil in the field capacity, applying non-saline water to each pot $\left(0.3 \mathrm{dS} \mathrm{m}^{-1}\right)$, with the volume to be applied determined according to the water requirements of the plants and estimated by the water balance: volume of water applied minus the volume of water drained in the previous irrigation, plus a fraction of 0.10. As shown in Figure 1 (water application per plant), the drained volume was replaced in the pots, in order to maintain the electrical conductivity in the soil saturation extract according to each treatment, being measured the soil conductivity at the end of the experimental cycle (Table 3).

During the crop cycle, the plants were transported vertically in a single stem with horizontally fixed wire loops, without apical meristem, as soon as the plants reached the height of $1.80 \mathrm{~m}$ (Figure 2). The fruits were fixed in the secondary branches, and the pruning in these branches was performed after the fruit was fixed, leaving two leaves. All other branches were eliminated. To support the fruits, nets made with PVC pipes and sisal strings were suspended in the wire of the conduction system (Figures $2 \mathrm{~B}$ and 2C).

In order to aid in the pollination, Frieseomelitta doederleini was introduced inside the greenhouse (Amano et al. 2000), during the flowering period of the crops.

At the beginning of flowering (30 DAT), measurements of $\mathrm{CO}_{2}$ assimilation rates (A), transpiration $(\mathrm{E})$, intercellular $\mathrm{CO}_{2}$ concentration $\left(\mathrm{C}_{I}\right)$

Table 1. Physical-chemical characteristics of the soil and manure components used in the experiment.

\begin{tabular}{|c|c|c|c|c|c|c|c|c|c|c|c|c|}
\hline & \multicolumn{12}{|c|}{ Chemical characteristics } \\
\hline & $\mathrm{pH}$ & $\mathrm{EC}$ & $\mathrm{P}$ & $\mathrm{K}$ & $\mathrm{Na}$ & $\mathrm{Ca}$ & $\mathrm{Mg}$ & $\mathrm{Al}$ & $\mathrm{H}+\mathrm{Al}$ & SB & $\mathrm{T}$ & $\mathrm{OM}$ \\
\hline & $\mathrm{H}_{2} \mathrm{O}(1: 2.5)$ & $\mathrm{dS} \mathrm{m}^{-1}(1: 5)$ & $\mathrm{mg} \mathrm{dm}^{-3}$ & \multicolumn{7}{|c|}{$\mathrm{cmol}_{\mathrm{c}} \mathrm{dm}^{-3}$} & - & $\mathrm{g} \mathrm{kg}^{-1}$ \\
\hline Soil & 6.50 & 0.32 & 56.36 & 0.36 & 0.07 & 1.20 & 0.71 & 0.10 & 0.81 & 2.34 & 3.15 & 4.79 \\
\hline \multirow[t]{4}{*}{ Manure } & 7.82 & 1.00 & 29.00 & 1.56 & 1.68 & 4.20 & - & 0.00 & 0.00 & 7.30 & 7.16 & 450 \\
\hline & \multicolumn{12}{|c|}{ Physical characteristics } \\
\hline & Sand & Silt & \multicolumn{2}{|c|}{ Clay } & & $\mathrm{k}$ densit & \multirow{2}{*}{\multicolumn{2}{|c|}{$\begin{array}{l}\text { True density } \\
\mathrm{cm}^{-3}\end{array}$}} & Total p & rosity & \multirow{2}{*}{\multicolumn{2}{|c|}{$\begin{array}{c}\text { Texture } \\
\text { class }\end{array}$}} \\
\hline & & $\mathrm{g} \mathrm{K}^{-1}$ & & & & + & & & $\mathrm{m}^{3}$ & & & \\
\hline Soil & 851 & 99 & \multicolumn{2}{|c|}{50} & & 1.64 & \multicolumn{2}{|c|}{3.10} & 0. & & \multicolumn{2}{|c|}{ Loamy sandy } \\
\hline
\end{tabular}

EC: electrical conductivity; SB: sum of bases; T: total cation exchange capacity; OM: organic matter.

Table 2. Chemical analysis of the water supply used in the preparation of the irrigations phase.

\begin{tabular}{|c|c|c|c|c|c|c|c|c|c|c|c|}
\hline \multirow{3}{*}{ Water } & $\mathrm{EC}$ & $\mathrm{pH}$ & $\mathrm{K}$ & $\mathrm{Ca}$ & $\mathrm{Mg}$ & $\mathrm{Na}$ & $\mathrm{SO}_{4}^{-2}$ & $\mathrm{CO}_{3}^{-2}$ & $\mathrm{HCO}_{3}^{-}$ & $\mathrm{Cl}^{-}$ & SAR \\
\hline & $\mathrm{dS} \mathrm{m}^{-1}$ & & & & & $\mathrm{nmo}$ & & & & 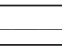 & $\left(\mathrm{mmol} \mathrm{L}^{-1}\right)^{0.5}$ \\
\hline & 0.3 & 7.0 & 0.3 & 0.2 & 0.6 & 1.4 & 0.2 & 0.0 & 0.8 & 1.3 & 2.21 \\
\hline
\end{tabular}

EC: electrical conductivity; SAR: sodium adsorption ratio. 
and stomatal conductance $(\mathrm{gS})$ were assessed with the portable photosynthesis measuring equipment "LCPro+" (ADC BioScientific Ltda.), in leaves completely expanded between $5^{\circ}$ and $6^{\circ}$, among nodes subjected to saturating irradiance $\left(1,000 \mu \mathrm{mol} \mathrm{m}^{-2} \mathrm{~s}^{-1}\right)$ provided by an external halogen lamp, to saturate the photosystems without causing damage. From these variables, the efficiency of the instantaneous carboxylation $\left(\mathrm{A} / C_{I}\right)$ and water use efficiency $(\mathrm{A} / E)$ were calculated. For determining the relative water content (RWC), leaf discs were collected and, according to those discs, the fresh mass (FM) was determined in a semi-analytical scale $(0.0001 \mathrm{~g})$. Then, the parts were incubated in distilled water for $4 \mathrm{~h}$ and the turgid mass (TM) was determined. Finally, the parts were dried in an oven at $70{ }^{\circ} \mathrm{C}$, for $48 \mathrm{~h}$, and the dry mass (DM) was determined. The RWC was calculated according to the relation described

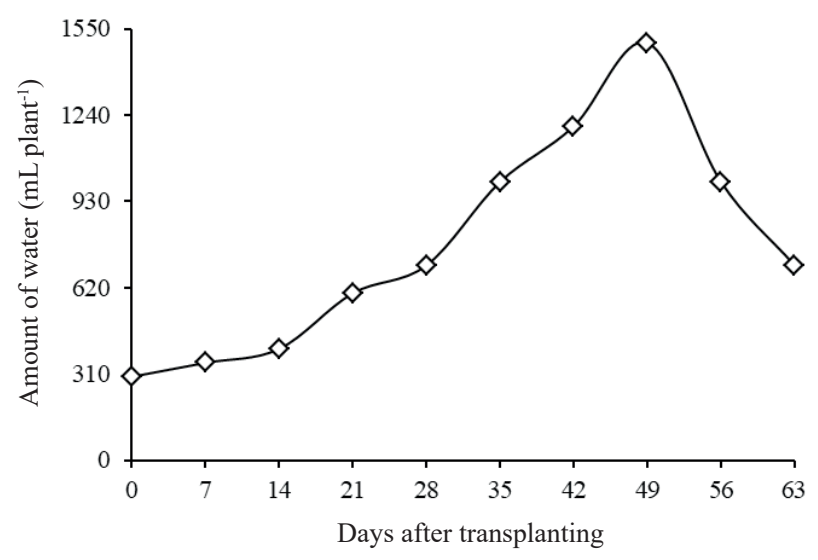

Figure 1. Average amount of water applied per plant during the experiment conduction. by Irigoyen et al. (1992): RWC $=(F M-D M / T M-$ DM) x $100(\%)$.

The degree of membrane integrity was estimated by electrolyte overtake, according to Lutts et al. (1996), with minor modifications. To achieve that, 10 leaf discs of $10 \mathrm{~mm}$ diameter were collected and placed in a test tube with $10 \mathrm{~mL}$ of deionized water and incubated in water bath at $25{ }^{\circ} \mathrm{C}$, for $6 \mathrm{~h}$. Then, readings were carried out to determine the electrical conductivity of the solutions (L1). Afterwards, the tubes were placed again in water bath for $1 \mathrm{~h}$, at $100{ }^{\circ} \mathrm{C}$, and new readings of the electrical conductivity of the solutions (L2) were made. The damage in the membranes, estimated by the percentage of electrolyte leakage, was evaluated by the relation: $\% \mathrm{VE}=(\mathrm{L} 1 / \mathrm{L} 2) \times 100$.

The average fruit weight was also assessed, with fruits being harvested as soon as they reached the physiological maturity, i.e., a yellow bark. After harvest, the fruits were weighed individually.

The obtained data were submitted to analysis of variance. The averages of the cultivar factor were

Table 3. Electrical conductivity of the saturation extract at the beginning and end of the experiment, in soil with melon cultivars.

\begin{tabular}{lllllll}
\hline \multirow{2}{*}{ Cultivar } & \multicolumn{6}{c}{ Electrical conductivity of the soil saturation extract } \\
\cline { 2 - 7 } & Initial ECs & 0.30 & 1.30 & 2.30 & 3.30 & 4.30 \\
\hline \multirow{2}{*}{ Iracema } & Final CEs & 0.35 & 1.37 & 2.34 & 3.35 & 4.36 \\
Goldex & Final CEs & 0.34 & 1.35 & 2.33 & 3.32 & 4.33 \\
Natal & Final CEs & 0.32 & 1.33 & 2.32 & 3.30 & 4.31 \\
\hline
\end{tabular}

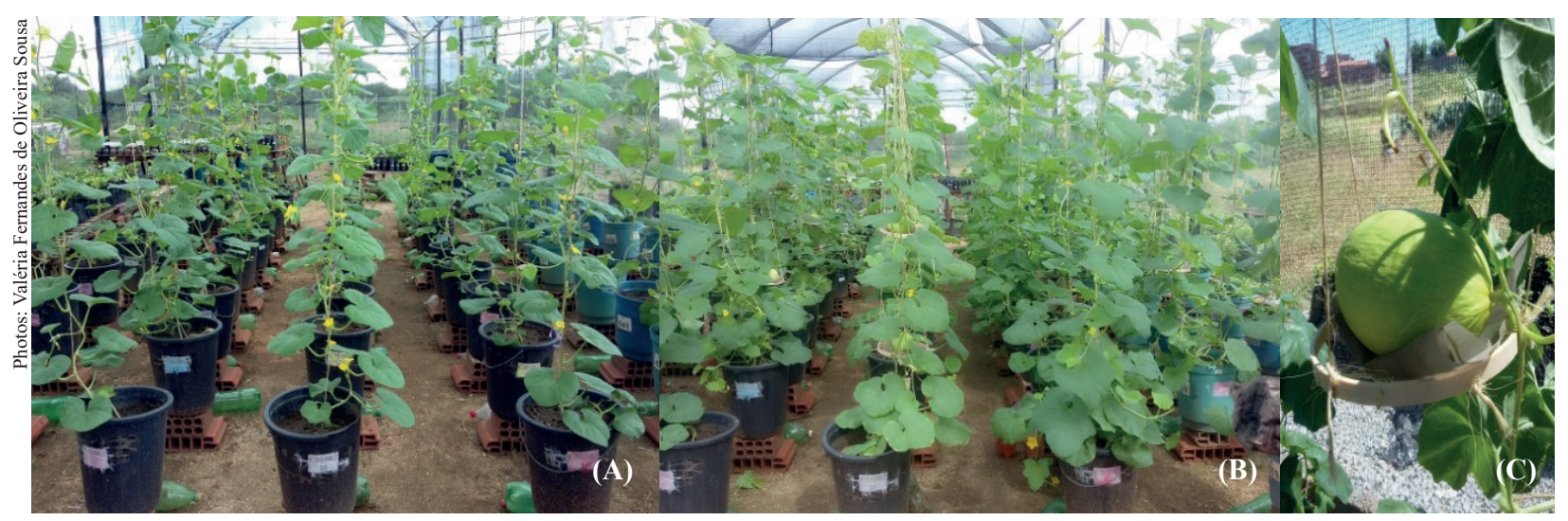

Figure 2. Flowering melon plants at 30 days after transplanting (DAT) (A), at the beginning of fruiting at 45 DAT (B) and the fruit on the support (C), submitted to saline levels in the soil. 
compared by the Tukey test at $5 \%$ of probability, while the averages resulting from the saline levels were submitted to regression analysis. The equations were chosen for the best adjustment and significance of the model. Statistical analyzes were performed using the Sisvar software, version 5.6 (Ferreira 2014).

\section{RESULTS AND DISCUSSION}

By analyzing melons physiologically, it was verified that a soil salinity of up to $1.02 \mathrm{dS} \mathrm{m}^{-1}$ promoted an increase in the net $\mathrm{CO}_{2}$ assimilation $\left(6.79 \mu \mathrm{mol} \mathrm{m} \mathrm{m}^{-2} \mathrm{~s}^{-1}\right)$, decreasing gradually from this plant saline level (Figure 3A). Probably, this reduction is related to photochemical damage, such as photoinhibition or photooxidation, or biochemical fixation of carbon under saline stress, thus interfering negatively in the plant development (Bosco et al. 2009, Cruz et al. 2017). Similar results were found by Melo et al. (2017), which showed decreases in gas exchange from $1 \mathrm{dS} \mathrm{m}^{-1}$. These authors denote that all the photosynthetic pigments decreased with the increase of electrical conductivity, with chlorophyll being more sensitive to salinity.

Dalastra et al. (2014) evaluated the gas exchange in three melon cultivars, conducted with one and two fruits, and found that the cultivars differed significantly, being Sancho superior to Medellin and Grand Prix, with $9.23 \%$ and $11.30 \%$, respectively. That is, there is diversity in the physiology of plants of the same species.

The stomatal conductance was significantly influenced by the interaction of the factors: the Goldex cultivar was negatively altered with the increase of the electrical conductivity of the soil, with declines of $4.46 \%$ at each unit increase in salinity. Usually, the plant, in response to the accumulation of salts in the leaf, provided the stomatal closure caused by the dehydration of the guiding cells, because the salts excess in the soil causes a decrease in the osmotic pressure (Hussain et al. 2015). Thus, the Iracema and Natal cultivars demonstrated acclimatization
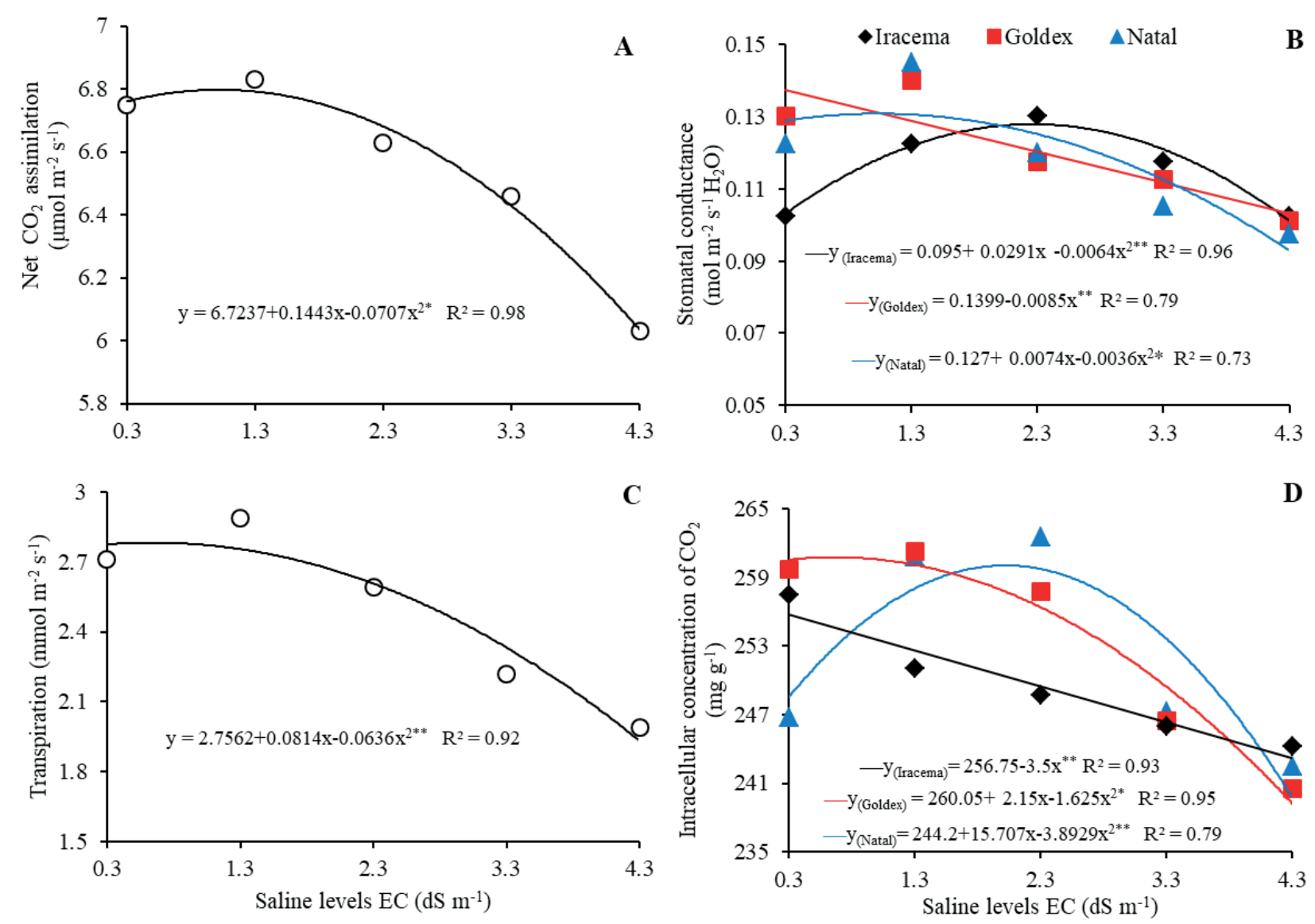

Figure 3. Net $\mathrm{CO}_{2}$ assimilation (A), stomatal conductance (B), transpiration (C) and intercellular concentration of $\mathrm{CO}_{2}(\mathrm{D})$, in melon cultivars submitted to soil salinity. 
stress conditions, with maximum points in the saline levels of $2.27 \mathrm{dS} \mathrm{m}^{-1}$ and $1.03 \mathrm{dS} \mathrm{m}^{-1}$, respectively (Figure 3B).

According to Melo et al. (2010), the study of physiological parameters, as stomatal conductance, is relevant in the clarification of the osmotic and water conditions effects on photosynthetic efficiency in plants and resulting yield.

The melons transpiration showed a $26.56 \%$ decline between the highest $\left(4.3 \mathrm{dS} \mathrm{m}^{-1}\right)$ and lowest $\left(0.3 \mathrm{dS} \mathrm{m}^{-1}\right)$ saline levels (Figure 3C). According to Ferraz et al. (2012), plants under stress conditions reduce the stomatal conductance and transpiration and increase the water use efficiency caused by the lag between root uptake and transpiration, so the partial closure of the stomata is a strategy to avoid excessive dehydration, or a consequence of water imbalance in the leaf epidermis (Ribeiro et al. 2009).

The intercellular $\mathrm{CO}_{2}$ concentration presented a reduction in the Iracema cultivar equivalent to $5.15 \%$, between the highest and lowest saline levels (Figure 3D). Bosco et al. (2009) studied the eggplant crop under saline stress in the irrigation water and found that there was an inversely proportional reduction with an increase in the electrical conductivity of the water (around $1 \%$ with each unit increment).

However, the Natal and Goldex cultivars exceed the intercellular $\mathrm{CO}_{2}$ concentration, with an increase up to $0.66 \mathrm{dS} \mathrm{m}^{-1}$ and $2.01 \mathrm{dS} \mathrm{m}^{-1}$, respectively, declining sharply from these levels. Higher $\mathrm{CO}_{2}$ concentrations support high photosynthetic rates, while, at very low intercellular $\mathrm{CO}_{2}$ concentrations, photosynthesis is limited (Dalastra et al. 2014). This photosynthetic variable is crucial for yield. According to Taiz et al. (2017), the internal concentration of $\mathrm{CO}_{2}$ is important, because the yield can be analyzed as the product of intercepted solar energy and $\mathrm{CO}_{2}$ fixed over a period.

Regarding the cultivars, regardless of saline concentrations, it was verified that the net $\mathrm{CO}_{2}$ assimilation was higher in the Iracema cultivar $\left(6.75 \mathrm{dS} \mathrm{m}^{-1}\right)$, surpassing in $4.74 \%$ and $4.59 \%$ the Goldex and Natal cultivars, respectively (Table 4). The difference in the physiological behavior among cultivars is due to a genotype variation, in response to the environment, being possible to select cultivars superior to others (Arantes et al. 2016).

It was observed in the efficiency of the instantaneous carboxylation that cultivars, separately from the saline levels, had a significant effect, with superiority for the Iracema cultivar, which obtained 0.0267 of carboxylation efficiency and increased by $4.86 \%$ and $3.37 \%$, in relation to the Goldex and Natal cultivars, respectively (Table 4). Thus, it is confirmed that the genetic difference between the cultivars leads to distinct responses, regardless of the environmental conditions they are exposed to. The instantaneous efficiency of carboxylation is a variable that has a close relation with the assimilation rate of carbon dioxide and with the intracellular $\mathrm{CO}_{2}$ concentration, since it is the ratio of both variables (Lima et al. 2017b). Because it is the result of a mathematical calculation, it may not have taken the expected interactive effect, being considered separately in the cultivar factor.

Regarding the relative water content of the leaf tissue, the Iracema and Goldex cultivars presented decreases of $66.71 \%$ and $41.45 \%$, with the increase of the electrical conductivity level of the soil up to $4.3 \mathrm{dS} \mathrm{m}^{-1}$. However, the Natal cultivar showed an increase of up to $0.42 \mathrm{dS} \mathrm{m}^{-1}$, with $85.63 \%$ of water content, decreasing from this level (Figure 4A). According to Silva et al. (2009), the values for relative content decreased in response to saline stress, negatively affecting the hydration degree of the tissues. In salinity conditions, the osmotic adjustment can be considered as an adaptive mechanism that allows the maintenance, under low water potentials, of the turgescence and its dependent processes, such as stomatal opening and water quantity in the cells (Souza et al. 2011).

By analyzing the percentage of membrane damage (extravasation of electrolytes) in the leaves, it is possible to infer that there is an increase proportional to the unit increase of the electrical conductivity of the soil of around $10.48 \%$ (Figure 4B), showing that, regardless of the cultivars studied, a degradation occurs in the leaf cell membranes, as a consequence

Table 4. Net $\mathrm{CO}_{2}$ assimilation $(A)$ and intercellular $\mathrm{CO}_{2}$ concentration $\left(C_{I}\right)$ of melon cultivars submitted to saline levels in the soil.

\begin{tabular}{|c|c|c|}
\hline Cultivar & $A\left(\mu \mathrm{mol} \mathrm{m}{ }^{-2} \mathrm{~s}^{-1}\right)$ & $A / C_{I}$ \\
\hline Iracema & $6.75 \mathrm{a}$ & $0.0267 \mathrm{a}$ \\
\hline Goldex & $6.43 \mathrm{~b}$ & $0.0254 \mathrm{~b}$ \\
\hline Natal & $6.44 \mathrm{~b}$ & $0.0258 \mathrm{ab}$ \\
\hline DMS & 0.29 & 0.0012 \\
\hline
\end{tabular}

*Averages followed by the same lowercase letter in the column do not differ statistically from each other by the Tukey test at $5 \%$ of probability. 

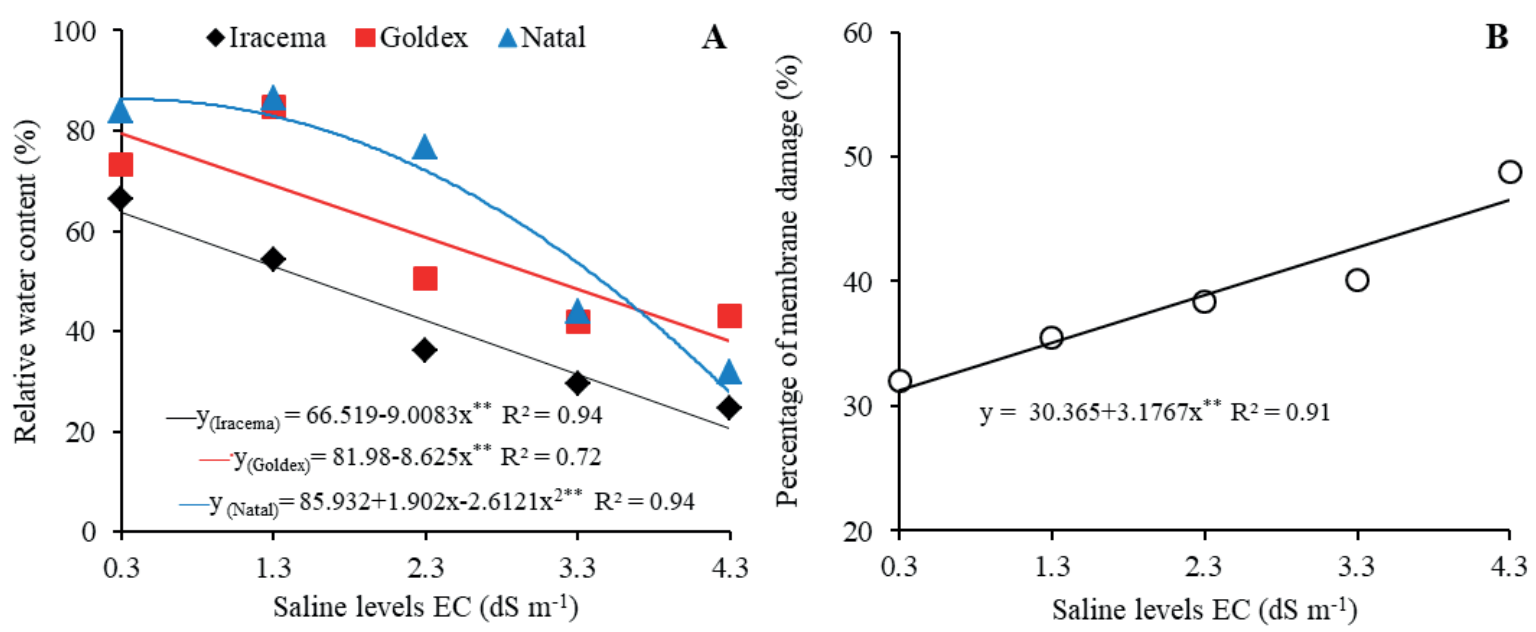

Figure 4. Relative water content (A) and percentage of membrane damage (B) in melon cultivars submitted to soil salinity.

of stress. Ferraz et al. (2015) state that this increase in cell extrusion is associated with the phytotoxicity caused by the excess of ions in the plant tissues, and this accumulation morphophysiologically modifies the composition of the membranes, causing ruptures. Karlidag et al. (2009), by evaluating the salinity in strawberry crops, found a similar behavior in the relative water content: a reduction in response to saline stress, while electrolyte extravasation increased.

The cultivars, together with the saline concentrations, interfered significantly in the average weight of the melon fruits. Although all the cultivars declined their production with the increase of saline concentrations, it was verified that the Natal cultivar stood out, in relation to the other ones, with $1,195.65 \mathrm{~g}$ in the treatment of $0.3 \mathrm{dS} \mathrm{m}^{-1}$, decreasing to $777.73 \mathrm{~g}$ in the saline level of $4.3 \mathrm{dS} \mathrm{m}^{-1}$, with a relative loss of $34 \%$ in the average weight of the fruits, but differing from the others up to the level of $3.3 \mathrm{dS} \mathrm{m}^{-1}$, due to the fact that this cultivar presents an average weight of $882.16 \mathrm{~g}$ at this saline level, being considered marketable (Figure 5).

For Lima et al. (2009), marketable fruits are those with a regular shape and weighing more than $800 \mathrm{~g}$ for yellow melon, in a protected environment. The other cultivars (Iracema and Goldex) expressed decreases of $34.12 \%$ and $37.48 \%$, respectively, and reached $995 \mathrm{~g}$ and $954 \mathrm{~g}$, at the level of $0.3 \mathrm{dS} \mathrm{m}^{-1}$, being lower than the Natal cultivar, in the same variable.

This genetic variability among melon cultivars, in acclimatization to salinity between cultivars of the same species, is demonstrated in some studies. For example,
Costa et al. (2013), evaluating Quetzali, Leopard and Shadow watermelon cultivars for fruit quality and yield, found that the Shadow cultivar was the most tolerant, in relation to the effect of electrical conductivity of the irrigation water, since it presented a smaller relative loss of the commercial production. In the plant, one of the characteristics of saline stress effect, according to Carmo et al. (2011), is the reduction in the production of photoassimilates correlated by the difficulty in the absorption and transport of nutrients, due to the limitation in the photosynthesis, which, consequently, causes growth and production restrictions.

In the present study, $63.33 \%$ of the harvested fruits had a weight greater than $800 \mathrm{~g}$ (i.e., considered marketable), while the non-marketable ones were mainly from the salt concentrations of $3.3 \mathrm{dS} \mathrm{m}^{-1}$ and

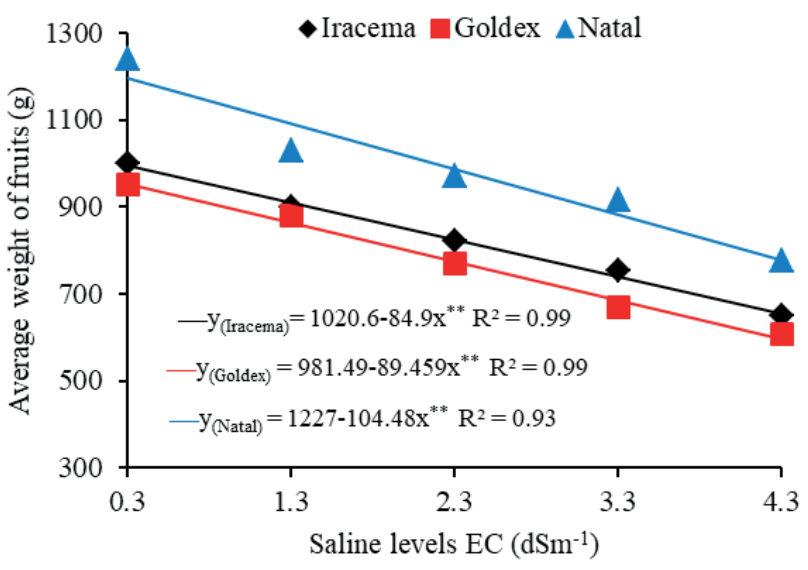

Figure 5. Average weight of fruits in melon cultivars submitted to soil salinity. 
$4.3 \mathrm{dS} \mathrm{m}^{-1}$, higher than the threshold salinity of the crop (Ayers \& Westcot 1999), thus demonstrating the depressive effect of salinity on production.

\section{CONCLUSIONS}

1. The melon physiology is negatively affected by the increased salinity in the soil;

2. The Iracema, Goldex and Natal cultivars do not show differences in tolerance for the physiological response to soil saline stress.

\section{REFERENCES}

AKRAMI, M.; ARZANI, A. Physiological alterations due to field salinity stress in melon (Cucumis melo L.). Acta Physiologiae Plantarum, v. 40, n. 91, p. 1-14, 2018.

AMANO, K.; NEMOTO, T.; HEARD, T. A. What are stingless bees, and why and how to use them as crop pollinators. Japan Agricultural Research Quarterly, v. 34, n. 3, p. 183-190, 2000.

ARANTES, A. M. et al. Gas exchange in different varieties of banana Prata in semi-arid environment. Revista Brasileira de Fruticultura, v. 38, n. 2, p. 1-12, 2016.

ARAÚJO, E. B. G. et al. Crescimento inicial e tolerância de cultivares de meloeiro à salinidade da água. Revista Ambiente \& Água, v. 11, n. 2, p. 462-470, 2016.

AYERS, R. S.; WESTCOT, D. W. A. A qualidade da água na agricultura. 2. ed. Campina Grande: Ed. UFPB, 1999.

BOSCO, M. R. O. et al. Efeito do $\mathrm{NaCl}$ sobre o crescimento, fotossíntese e relações hídricas de plantas de berinjela. Revista Ceres, v. 56, n. 3, p. 296-302, 2009.

CARMO, G. A. et al. Teores foliares, acúmulo e partição de macronutrientes na cultura da abóbora irrigada com água salina. Revista Brasileira de Engenharia Agrícola e Ambiental, v. 15, n. 5, p. 512-518, 2011.

CASTILHOS, L. F. F. Cultivo de melão e melancia. Curitiba: Tecpar, 2012.

CHAVES, M. M.; FLEXAS, J. E.; PINHEIRO, C. Photosynthesis under drought and salt stress: regulation mechanisms from whole plant to cell. Annals of Botany, v. 103, n. 4, p. 551-560, 2009.

COSTA, A. R. F. C. et al. Produção e qualidade de melancia cultivada com água de diferentes salinidades e doses de nitrogênio. Revista Brasileira de Engenharia Agrícola e Ambiental, v. 17, n. 9, p. 947-954, 2013.

CRUZ, J. L. et al. Salinity reduces carbon assimilation and the harvest index of cassava plants (Manihot esculenta
Crantz). Acta Scientiarum Agronomy, v. 39, n. 4, p. 545555, 2017.

DALASTRA, G. M. et al. Produção e qualidade de três tipos de melão, variando o número de frutos por planta. Revista Ceres, v. 63, n. 4, p. 523-531, 2016.

DALASTRA, G. M. et al. Trocas gasosas e produtividade de três cultivares de meloeiro conduzidas com um e dois frutos por planta. Bragantia, v. 73, n. 4, p. 365-371, 2014.

DIAS, N. S. et al. Concentração salina e fases de exposição à salinidade do meloeiro cultivado em substrato de fibra de coco. Revista Brasileira de Fruticultura, v. 33, n. 3, p. 915-921, 2011.

ESTEVES, B. S.; SUZUKI, M. S. Efeito da salinidade sobre as plantas. Oecologia Brasilensis, v. 12, n. 4, p. $662-$ 679, 2008.

FERRAZ, R. L. S. et al. Trocas gasosas e eficiência fotossintética em ecótipos de feijoeiro cultivados no Semiárido. Pesquisa Agropecuária Tropical, v. 42, n. 2, p. 181-188, 2012.

FERRAZ, R. L. S. et al. Photosynthetic pigments, cell extrusion and relative leaf water content of the castor bean under silicon and salinity. Revista Brasileira de Engenharia Agrícola e Ambiental, v. 19, n. 9, p. 841-848, 2015.

FERREIRA, D. F. Sisvar: a guide for its bootstrap procedures in multiple comparisons. Ciência e Agrotecnologia, v. 38, n. 2, p. 109-112, 2014.

FOOD AND AGRICULTURE ORGANIZATION (FAO). Produção mundial do meloeiro. 2017. Available at: $<\mathrm{http}$ // faostat3.fao.org/download/T/TP/E>. Access on: 25 Jun. 2018.

HUSSAIN, M. I. et al. Salt and drought stresses in safflower: a review. Agronomy for Sustainable Development, v. 36, n. 1, p. 1-31, 2015.

INSTITUTO BRASILEIRO DE GEOGRAFIA E ESTATÍSTICA (IBGE). Produção agrícola municipal: lavouras permanentes. 2017. Available at: $<$ https:// www.ibge.gov.br/estatisticas-novoportal/economicas/ agricultura-e-pecuaria/9117-producao-agricolamunicipal-culturas-temporarias-e-permanentes. $\mathrm{html} ?=\& \mathrm{t}=$-resultados $>$. Access on: 25 Jun. 2018.

IRIGOYEN, J. J.; EMERICH, D. W.; SÁNCHEZ-DÍAZ, $M$. Water stress induced changes in concentrations of proline and total soluble sugars in nodulated alfalfa (Medicago sativa) plants. Physiology Plantarum, v. 84, n. 1, p. 67-72, 1992.

KARLIDAG, H.; YILDIRIM, E.; TURAN, M. Salicylic acid ameliorates the adverse effect of salt stress on strawberry. Scientia Agricola, v. 66, n. 2, p. 180-187, 2009. 
LIMA, E. M. C. et al. Crescimento e produção de melão cultivado em ambiente protegido e irrigado por gotejamento. Irriga, v. 14, n. 4, p. 449-457, 2009.

LIMA, G. S. et al. Growth and yield of colored-fiber cotton grown under salt stress and nitrogen fertilization. Revista Brasileira de Engenharia Agrícola, v. 21, n. 6, p. 415-420, 2017a.

LIMA, G. S. et al. Trocas gasosas, pigmentos cloroplastídicos e dano celular na mamoneira sob diferentes composições catiônicas da água. Irriga, v. 22, n. 4, p. 757-774, 2017 b.

LIU, X. E.; HUANG, B. Photosynthetic acclimation to high temperatures associated with heat tolerance in creeping bentgrass. Journal of Plant Physiology, v. 165, n. 18 , p. 1947-1953, 2008.

LUTTS, S.; KINET, J.; BOUHARMONT, J. NaCl induced senescence in leaves of rice (Oryza sativa) cultivars differing in salinity resistance. Annals of Botany, v. 78, n. 3, p. 389-398, 1996.

MEDEIROS, J. F. et al. Management strategies of saline water on morphometric characteristics of melon cultivars. Engenharia Agrícola, v. 34, n. 4, p. 649-659, 2014.

MELO, A. S. et al. Crescimento vegetativo, resistência estomática, eficiência fotossintética e rendimento do fruto da melancieira em diferentes níveis de água. Acta Scientiarum Agronomy, v. 32, n. 1, p. 73-79, 2010.

MELO, H. F. et al. Trocas gasosas e pigmentos fotossintéticos em pimentão irrigado com água salina. Revista Brasileira de Engenharia Agrícola e Ambiental, v. 21, n. 1, p. 38-43, 2017.

MENDES, A. M. S. et al. Sistema de produção de melão. Petrolina: Embrapa Semiárido, 2010.
MUNNS, R.; TESTER, M. Mechanisms of salinity tolerance. Annual Review of Plant Biology, v. 59, n. 1, p. 239-250, 2008.

NOVAIS, R. F.; NEVES, J. C. L.; BARROS, N. F. Ensaio em ambiente controlado. In: OLIVEIRA, A. J. et al. (Eds.). Métodos de pesquisa em fertilidade do solo. Brasília, DF: Embrapa-SEA, 1991. p. 189-255.

PEREIRA, F. A. L. et al. Tolerance of melon cultivars to irrigation water salinity. Revista Brasileira de Engenharia Agricola e Ambiental, v. 12, n. 12, p. 846-851, 2017.

RIBEIRO, R. V. et al. Photosynthesis and water relations of well-watered orange plants as affected by winter and summer conditions. Photosynthetica, v. 47, n. 2, p. $215-$ 222, 2009.

RICHARDS, L. A. Diagnosis and improvement of saline and alkali soils. Washington, DC: USDA, 1954.

SANTOS JÚNIOR, J. A. et al. Doses de boro e água residuária na produção do girassol. Revista Ciência Agronômica, v. 42, n. 4, p. 857-864, 2011.

SILVA, E. N. et al. Contribuição de solutos orgânicos e inorgânicos no ajustamento osmótico de pinhão-manso submetido à salinidade. Pesquisa Agropecuária Brasileira, v. 44, n. 5, p. 437-445, 2009.

SOUZA, R. P. et al. Fotossíntese e acúmulo de solutos em feijoeiro caupi submetido à salinidade. Pesquisa Agropecuária Brasileira, v. 46, n. 6, p. 586-592, 2011.

TAIZ, L. et al. Fisiologia e desenvolvimento vegetal. 6. ed. Porto Alegre: Artmed, 2017.

TERCEIRO NETO, C. P. C. et al. Produtividade e qualidade de melão sob manejo com água de salinidade crescente. Pesquisa Agropecuária Tropical, v. 43, n. 4, p. 354-362, 2013. 